\title{
Youth Restiveness in Nigeria: Challenge for Counselling
}

\author{
Dr (Mrs.) Stella Ngoz Induka-Ozo ${ }^{1}$, Dr. Igba Daniel Igba ${ }^{2}$ \\ ${ }^{1}$ Department of Educational Foundations, Ebonyi State University, Abakaliki. \\ ${ }^{2}$ Department of Arts and Social Science Education, Ebonyi State University, Abakaliki.
}

\begin{abstract}
The paper examined the meaning of youth restiveness in Nigeria, its causes and challenge for counselling. The youths were seen as young people who are still in the most active period of their lives. They are cognitively capable of hypothetical deductions, analysis and synthesis of situations by which they find themselves. They are restive; in other words impatient, obstinate and agitated especially when they are not satisfied with the state of things around them. The complexity of modern life makes the situation to be even more difficult for the youths, while the Nigerian factor further complicates matters for them. Some of the factors that contributed to the restiveness of youths in Nigeria include: leadership styles, economic situation, educational pursuits, poverty, unemployment, marginalization, exuberance, drugs, sexually transmitted diseases and activities of significant adults in the communities. Good guidance and counselling were seen as possible strategies that could help in harnessing the inert potentials of the youths and channeling them into vehicles for national development (if the challenges are dealt with); otherwise their restiveness could become fuel for maladaptive and mal-adjustive behaviour, thus constituting social problems for the nation as a whole.
\end{abstract}

Keywords-Youth, Restiveness, Counselling, Challenges, Nigeria.

\section{INTRODUCTION}

The youths are young people between the ages of 13 and 30. Although some older people may still be young at heart. Among these people are the teenagers and young adults who may still be carrying over the characteristics of adolescence the period of storm and stress, the period when the sleeping lion awakes as explained by Freud (1943), (the psychic energy having moved to the genital organs in the form of sexual excitation). The youths arevibrant, energetic, inquisitive, adventurous, gregarious, risk takers and identity seekers; all these make them to be restive. Restiveness is the inability to be still or quiet or having difficulty in being controlled, especially when one is not satisfied with something. The youths often clash with the adults, having arrived at the apex of intelligence (Piaget, 1964), and therefore capable of hypothetical deductions, analyses and syntheses of adults' intentions.

The complexity of modernization makes life even more complicated for today's youths. Today's youths are, therefore, youngsters who have grown up under the threat of having no future at all because of the poverty level of the common man; especially in Nigeria. Wars, ecological disaster, economic chaos and bad government all loom large on their horizon, (Watchtower2004).

Today's youth have more time on their hands than they know what to do with, since adults around are too busy to care; and so they have to cope with the influence of peer pressure. They are in an age of technological advancement and computerized 'this and that' the good, the bad and the ugly. Today's youth have become addicted to TV viewing and so influenced by excessive display of cruelty, nudity and erotic movies which are often mental fuel for evil. They have become involved with drugs, alcohol and cultism in such high degree that these have affected their emotional growth. Many youths are the victims of harassment by peers in cults or opposing political thugs during electioneering campaigns; including the 'use and drop' that follows after such elections. They are faced with unwanted and teenage pregnancy, in addition to the scourge of STDs and HIV/AIDS; since they appear to be the most vulnerable victims. Medinnus and Johnson (1976) outlined a number of developmental tasks that the youths have to accomplish, which includes:

- Achieving more masculine or feminine role.

- Achieving assurance of economic independence and selectingand preparing for an occupation.

- Developing intellectual skills and concepts necessary for civiccompetence.

- Desiring and achieving socially responsible behaviour.

- Acquiring a set of values and an ethical system. 
- Achieving new and more mature relations with age mate of both sexes.

- Accepting one's physique and using the body effectively.

- Achieving emotional independence from parents and other adults.

- Preparing for marriage and family life.

\section{THE NIGERIAN SITUATION}

The problems that many youths have to grapple with in Nigeria are numerous and include: not having good models around them, lack of employment, living in a society that accepts evil, perverse values and unethical practices, and not being in positions that will allow them to use their skills, competence and their youthful energy. Ogbeifun (2007) grouped the restiveness of the Niger Delta youths into three categories:

- Youths engaged in genuine agitation for their rights and restoration of the dignity of Niger Deltans.

- Youths engaged in a self-seeking and criminal activities.

- Youths who are seeking revenge for the "use and dump" attitude of elites in the region.

In all concluded Ogbeifun (2007) maintained that there is a unifying factor in the rationalization of their actions as expressed in their definitions, which is not being satisfied with their present state. One can safely say that what is true of the Niger Delta can be generalized for the whole country. In the same year Ogbuagu (2007) opined that Nigeria is truly the giant of Africa because if what goes on in Nigeria happens in any other country of Africa it could lead to that country's disintegration. Continuing he argued that Nigeria is blessed with oil, minerals, agricultural produce, great men and women, yet some people are suffering in penury - no good roads, no accommodation, no steady electricity, no employment, no good food, and no future for the oncominggeneration.

The present perverted values which the Nigerian Youths have to live with may be seen through the following: leadership styles in Nigeria, Economic situations and educational pursuits; as seen by Nduka-Ozo (2010).

\section{Leadership Styles in Nigeria:}

Nigeria is supposed to be a democratic nation. Democracy has been defined by Nweze(20I0:193) as:

Government which, in the purest form, holds that the State should be controlled by all the people, each sharing equally in privileges, duties and responsibilities and each participating in person in the government. In practice, control is vested, in elective officers as representatives who may be upheld or removed by the people.

On the contrary, election into offices in Nigeria has become 'selection'. During campaigns we see Messiahs, visions, and God 'sents'; but the moment they are voted in by election or selection they show their true colours. Their false promises, Ogbuagu (2007) lamented - of food for all, education for all, electricity for all, wives for all, houses for all etc turn to sealed lips for all - otherwise if anybody makes noise, 'eliminate him'. Such leaders (Life-term aspirants) begin to use the people's money for personal gain, carry away money to foreign countries, entertain visitors (who do not add to the economic welfare of the country) with millions of naira; use panel of inquiries to cover up crimes, yet money recovered from looters are never accounted for. Odey (2010) opined that he could not see how the we will recover the wasted years of our nationhood in a situation where every man goes scot-free with his loot and Nigeria is condemned ahead without looking at the past. Political thuggeryusing youths as sandwiches become acceptable, because the youths are sent out of their careers and academic pursuits at the sight of little money, meant to entice them. In such situations, the youths divert their God given energy to negative avenues, since their energy must be expended somehow.

\section{Economic situation:}

Resource control problems appear to loom large in this giant of Africa. Sharing the proceeds from our God given resources Ogbuagu (2007) also lamented become a problem when dichotomy, on-shore/offshore, dis-advantaged States and such 'ecliche' are used for sharing. Even business houses are dominated by such falsehood that an unsuspecting buyer can go home with two cups of garri for ten that he actually paid for. From my personal experience, it appears that everything in Nigeria has the 'real' and the 'fake', and if only they should be well identified one can at least decide on the one he wants.

Many Nigerians are faced with making quick money, leading to the youths desiring to drop out of school to join the bandwagon. Depression and frustration then set in when the dreams of such youths are not actualized. Many of them decide to travel out to other countries to do menial jobs, or become criminals instead of remaining in 'Papa's Land ${ }^{1}$ and see themselves excluded from their birth-rights.

\section{Educational pursuits:}


Nigerian youths have a situation on their hand when it comes to educational pursuits. Odey (2010:22) commented that:

"when you are face to face with an educational system under which many young men remain in lecture rooms during the day, but sneak out in the night with lethal weapons to destroy, to rob, to maim and to kill people with impunity you will understand".

An average youth manages to write WAEC amidst all kinds of examination mal-practices, he scrambles through JAMB (through special centres); centres where they pay money to pass and manages to matriculate in any University that agrees to take him. There, he is faced with 'sorting and cheating ${ }^{1}$ (paying money) at examinations and other academic dishonesty, which make him to run a serious risk of harming his future educational and employment opportunities. Everything has a price (cash or kind) in some of the so-called citadels of Excellence - people pay to pass examinations, for project topics, for defense of their project topics and even for teaching practice that was never done. No wonder people decide to just pay for the certificates at the business centres and save themselves the trouble of waiting for four, five or even six years to get the same certificates.

Other factors: Chukwuezi (2009), in her own contribution saw youthful exuberance and other factors like poverty, unemployment, marginalization, drugs and activities of the oilcompanies as contributing to restiveness of most Nigerian youths, especially the Niger Deltans. It is dismal to note that the youths are part and parcel of a society where money is being squandered by some; while the majority of the populace lives below poverty line. In some cases the youths are the very drivers, servants, gatekeepers and stewards to thesquander maniacs'. Nobody can flog a child and expect that same child not to cry.

\section{Implication/Challenge in Counselling for Youth Restiveness:}

One major strategy for remediation of problems is through guidance and counselling. Shertzer and Stone (1976) defined Guidanceas the process of helping individuals to understand themselves and their world. This definition implies that the programme involves a series of actions aimed towards achieving a goal. Counselling as Mallum (1990:14) saw it is an interpersonal relationship, usually between two individuals, a Counsellor and a Client, in which the principal objectives are the development of the client, the improvement of his welfare and the amelioration of his problems. The implication of this definition is that the youths have their developmental tasks and problems which should not be taken for granted or sub-summed in their restiveness, they need counselling to be able to adjust in the 'adult' dominated societies that they find themselves. Another angle to the amelioration of their problems could also be in the counselling of significant individuals who relate with the youths in various ways and their attitude towards the needs of youths.

The Federal Republic of Nigeria (2004) had enumerated the rationale for the introduction of Guidance and Counselling in schools, yet in the year 2011 the discipline has not been fully enthusiastically embraced. It is still facing problems such as: paucity of trained counsellors, relative newness of the programme, doubts about itsefficacy, blurred role or the counsellor, resistance by other colleagues, issue of confidentiality lack of Government's commitment, inadequate funding and paucity of psychological tests (Kolo. 1992 and Idowu, 1998).

Chukwuezi (2009) commented that in the past youths were perceived as heroes of the nationalist movement, militants in the anti-colonial struggle, and have rendered valuable contributions to the struggle for liberation and national development; earning them such names as people acting under harmless "youthful exuberance". (Onoge, 2004). What then went wrong with the present day youths -- where did they miss their focus? It is the belief of this paper that with proper guidance and counselling the youths can still constitute a reservoir of energy and dynamism needed for national development. On the other hand, if left un-guided, with the problem of unemployment, poverty, moral bankruptcy and the scourge of various sexually transmitted diseases, they will continue to constitute major social problems. Their potentials as future leaders and great professionals could be channeled into other negative, maladjustive and mal-adaptive behaviours and activities. Ekwe (1986) opined that the youths are not beyond academic and moral redemption if only there will be a motivating will channeled through counselling and love.

\section{CONCLUSION}

In view of the fact that youth restiveness is caused by leadership styles, economic situation, educational pursuits, poverty, unemployment, marginalization, exuberance, drugs, sexually transmitted diseases and activities of significant adults in the communities, guidance and counselling have been suggested as possible strategies that could help in harnessing the inert potentials of the youths and channeling them into vehicles for national development. However, even counselling the youths has the 
problem of acceptability as an intervention process. If the youths are not attended to, their restiveness could become fuel for mal-adaptive and mal-adjustive behaviour, thus constituting social problems for the nation as a whole. Measures should, therefore, be taken to provide good models for the youths; in addition to taking care of the various problems that they face (in the situations mentioned above); while trying to actualize their dreams and aspirations. It should always be remembered that the youths have some developmental tasks that must be accomplished by them; they only need the enabling environment.

\section{REFERENCES}

[1] Chukwuezi, C.O. (2009) Poverty and Youth Restiveness in Nigeria: Implication for National Development. Journal of Social Sciences. 2 (2)

[2] Ekwe, A.O. (1986). Helping Nigerian Youths achieve self-actualization: A Task for the Counsellor. In Psychology and Society. Selected Readings - Eileen B. Wilson (Ed). He Ife: University of Ife Press Ltd.

[3] Federal Republic of Nigeria (2004). National policy on education. Lagos: NERDC. (36-38).

[4] Freud, S. (1943). A General Introduction to Psychoanalysis. Garden City N.Y.R: Garden City Books.

[5] Idowu, A.I. (1998). Guidance and Counselling in Education, llorin: Inderac.

[6] Kolo, FD. (1992). Guidance and Counselling in Perspective. Zaria: Steveno.

[7] Mallum, M. (1990), Guidance and Counselling in Secondary Schools. Ibadan: Evans Brothers Nigeria Publishers Ltd.

[8] Medinnus, G.R. \& Johnson, R.C. (1976). Child and Adolescent Psychology. New York: John Wiley \& Sons.

[9] Nduka-Ozo, S.N. (2010), Value Re-orientation of Nigerian Youths. Paper presented at the $2^{\text {nd }}$ National Annual Conference of Nigerian Society for Psychical Research at Micheal Okpara University, Umudike.

[10] Nweze, T. (2010). Nine years of Democracy dividends in Ebonyi State: A critical assessment of the journey so far in the education sector. Ebonyi State: Themes \& Prospects of a New Social Order -Anniversary Lecture Series Vol. I. Abakaliki: Ebonyi State Government.

[11] Odey, J. (2010). Recovering the wasted years of Nigerian Nationhood -The role of justice and fair play. Ebonyi State: Themes \& Prospects of a New Social
Order - Anniversary Lecture Series Vol. I. Abakaliki: Ebonyi State Government.

[12] Ogbeifun, L.B. (2007). Youth Restiveness in Niger Delta: Issues and Imperatives. A Paper presented to the National Union of Petroleum and Gas workersof Nigeria, Port-Harcourt Zone at MODOTEL, Owerri, Nigeria.

[13] Ogbuagu, U. (2007). The Giant of Africa. An unpublished but waxed music.

[14] Onoge, O.F. (2004), Urhobo Youth and the Urhobo Future. An Address at the Fifth Annual Conference of Urhobo Historical Society.

[15] Piaget, J. (1964). Cognitive Development in Children: Piaget Development and Learning. Journal of Research in Science Teaching. 2 (3), 176 $-186$.

[16] Shertzer, B. \& Stone, S.C., (1976). Fundamentals of Guidance. Boston: Houghton Mifflin Coy.

[17] Watchtower. (2004). The Questions That Young People Ask. Jehovah Witness. 